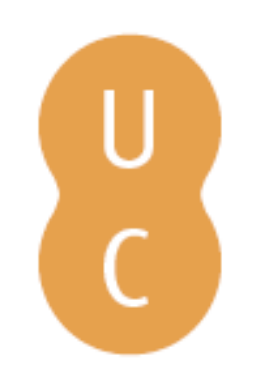

\title{
pompalina
}

Cícero e Ovídio: o poder da Vxor em contexto de exílio

Autor(es): $\quad$ Oliveira, Emília M. Rocha de; Torrão, João M. Nunes

Publicado por: Centro de Estudos Clássicos e Humanísticos; Imprensa da Universidade de Coimbra

URL

persistente: URI:http://hdl.handle.net/10316.2/31686

DOI: $\quad$ DOI:http://dx.doi.org/10.14195/978-989-8281-47-0_11

Accessed : $\quad$ 26-Apr-2023 06:55:21

A navegação consulta e descarregamento dos títulos inseridos nas Bibliotecas Digitais UC Digitalis, UC Pombalina e UC Impactum, pressupõem a aceitação plena e sem reservas dos Termos e Condições de Uso destas Bibliotecas Digitais, disponíveis em https://digitalis.uc.pt/pt-pt/termos.

Conforme exposto nos referidos Termos e Condições de Uso, o descarregamento de títulos de acesso restrito requer uma licença válida de autorização devendo o utilizador aceder ao(s) documento(s) a partir de um endereço de IP da instituição detentora da supramencionada licença.

Ao utilizador é apenas permitido o descarregamento para uso pessoal, pelo que o emprego do(s) título(s) descarregado(s) para outro fim, designadamente comercial, carece de autorização do respetivo autor ou editor da obra.

Na medida em que todas as obras da UC Digitalis se encontram protegidas pelo Código do Direito de Autor e Direitos Conexos e demais legislação aplicável, toda a cópia, parcial ou total, deste documento, nos casos em que é legalmente admitida, deverá conter ou fazer-se acompanhar por este aviso.

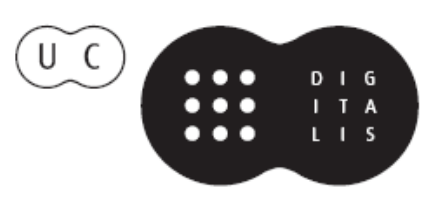




\section{Sociedade, Poder e Cultura no Tempo de Ovídio}

Maria Cristina de Sousa Pimentel e Nuno Simões Rodrigues (Coords.) 


\title{
Cícero e Ovídio: O PODER DA VXOR EM CONTEXTO DE EXÍLIO
}

\author{
Emília M. Rocha de Oliveira \\ Universidade de Aveiro \\ JoÃo M. Nunes ToRrÃo \\ Universidade de Aveiro
}

O poder, como todos sabemos, pode ser exercido de variadas maneiras e, nos seus limites, pode passar por uma evidência clara do seu exercício, como é o caso de quem exerce cargos políticos, até a um quase completo e, às vezes, propositado apagamento dos traços visíveis da sua acção, como fazem os que, na sombra, por motivos nobres ou nem por isso, influenciam as decisões mais importantes que têm vindo a ser tomadas no governo dos diversos povos. Além disso, pode assumir envolvências diversas que passam pelo poder psicológico, pelo poder moral, pelo poder de intervenção, pelo poder político, entre outras. $\mathrm{Na}$ antiga Roma, o desempenho de funções reconhecidamente públicas encontrava-se vedado às mulheres. Embora estas tivessem conquistado paulatinamente alguma liberdade social e significativa independência ao nível da lei privada, no âmbito da lei pública, o seu estatuto permaneceu bastante limitado ${ }^{1}$. Indirectamente, porém, - ou melhor, sem assumirem um evidente protagonismo - as mulheres desempenhavam um papel importante e, por vezes, decisivo no curso da história política de $\mathrm{Roma}^{2}$, mas aquelas que foram além das funções tradicionalmente definidas para o sexo feminino causaram alguma tensão na sociedade romana ${ }^{3}$, de tal modo que se pode dizer que a sociedade patriarcal romana condenava qualquer incursão feminina no mundo da política ${ }^{4}$.

1 A única forma de intervenção pública da qual as mulheres não se encontravam absolutamente excluídas era a esfera religiosa. Veja-se o exemplo do colégio das Vestais. As seis sacerdotisas eram, de certa forma, tratadas como homens; participavam em banquetes públicos, tinham acesso a lugares de honra nos jogos e o direito de fazer os seus próprios testamentos. Cf. FAnTham (1994) 225, 235-237.

${ }^{2}$ Cf. Bauman (1992) XII, XIII, 2. Veja-se também o fortíssimo papel desempenhado por Augusta em toda a acção do primeiro princeps de Roma.

${ }^{3}$ Cf. Bauman (1992) 10-12; Fantham (1994) 326.

${ }^{4}$ Veja-se o exemplo de Semprónia, que, juntamente com outras mulheres de elevada estirpe, apoiou a conspiração de Catilina para derrubar o governo do ano 63 a. C. Salústio descreve-a como uma mulher perversa, e imoral, que usa os atributos de mulher ideal para fins subversivos: Sed in eis erat Sempronia, quae multa saepe uirilis audaciae facinora commiserat. Haec mulier genere atque forma, praeterea uiro atque liberis satis fortunata fuit; litteris Graecis et Latinis docta, psallere et saltare elegantius, quam necesse est probae, multa alia, quae instrumenta luxuriae sunt. Sed ei cariora semper omnia quam decus atque pudicitia fuit; pecuniae an famae minus paceret, haud facile discerneres; lubido sic accensa, ut saepius peteret uiros quam peteretur. Sed ea saepe antehac fidem prodiderat, creditum abiurauerat, caedis conscia fuerat, luxuria atque inopia praeceps abierat. Verum ingenium eius haud absurdum; posse uersus facere, iocum mouere, sermone uti uel modesto uel molli uel procaci; prosus multae facetiae multusque lepos inerat. (Sal., Cat. 25). Independentemente de esta descrição corresponder ou não à realidade, o ataque de Salústio à moralidade desta mulher revela 
No final da República, as mulheres de condição social elevada tinham uma margem de liberdade considerável, eram detentoras de bens consideráveis que geriam conforme a sua vontade, eram cultas e tinham a sua própria vida social. Por vezes, podiam até intervir na vida pública, lidando com questões estritamente relacionadas com os interesses da família ${ }^{5}$, mormente em situações em que marido e mulher eram obrigados a separar-se um do outro. Circunstâncias específicas como o exílio do marido, a assunção por parte deste do governo de uma província, ou, ainda, o cumprimento do serviço militar davam à esposa a oportunidade de sair da esfera doméstica a que tradicionalmente estava confinada para entrar na esfera pública, em regra reservada ao homem; a mulher tinha de cuidar da família e olhar pelos interesses do marido ${ }^{6}$. Em situações como estas, a assunção de uma posição de liderança e poder por parte da mulher no seio da família, perspectivada pelo casal como natural e necessária, não provocava qualquer tipo de tensão ou desarmonia conjugal. Afinal, o objectivo era velar pelo bem de todos os indivíduos que compunham a célula familiar.

O exílio, em particular, dava origem a uma situação muito especial no relacionamento entre marido e mulher. Ao contrário do que hoje acontece nas sociedades ocidentais, não existiam na sociedade romana partidos políticos, organizações não governamentais ou instituições de caridade que pudessem prestar apoio emocional, político e financeiro a indivíduos que viviam exilados. Era à família e aos amigos mais chegados que cabia prestar apoio ao exilado, defendendo os seus interesses em Roma. Em situação de exílio

o desconforto da sociedade romana em relação a mulheres que ousavam ultrapassar os limites impostos à sua condição. Semprónia não é exemplo único de uma mulher do final da República familiarizada com o sistema político romano, que ousou libertar-se do papel que tradicionalmente a confinaria ao lar, para agir na esfera pública. Clódia, irmã do tribuno da plebe P. Clódio Pulcro e suposta amante de Catulo (geralmente identificada com Lésbia), desempenhou um papel importante no julgamento do seu anterior amante, M. Célio Rufo. Após Célio ter posto fim a esta relação amorosa, Clódia procurou vingança, aliando-se a L. Semprónio Atratino, filho de L. Calpúrnio Béstia, que tinha sido acusado por Célio de corrupção eleitoral em 56 a. C., mas que acabou por ser considerado inocente. Quando Béstia se candidatou a pretor no final desse mesmo ano, quis silenciar Célio como forma de prevenir outro ataque do seu inimigo. Clódia e Béstia uniram-se então, como aliados políticos, contra Célio, usando o tribunal criminal público para alcançarem os seus intentos. Cf. Grebe (2003) 134 sq.

${ }^{5}$ Cf. CAry (1970) 456 sq.

${ }^{6}$ Cf. Grebe (2003) 134. O mesmo autor apresenta Fúlvia como um dos exemplos mais conhecidos de mulheres politicamente activas neste período. Enquanto o seu terceiro marido, Marco António, esteve no Oriente, ela velou pelos interesses dele em Roma (Plu., Ant. 28.1). Após a derrota em Mútina no ano 43 a. C., Fúlvia impediu que ele fosse declarado inimigo público (App., $B C$ 3.51). Posteriormente, no início do conflito entre Octaviano e Marco António, exortou publicamente os soldados do marido a manterem-lhe a fidelidade. (App., $B C$ 5.14). Além dos exemplos de Semprónia, Clódia e Fúlvia, o mesmo autor (cf. 135, n. 28) refere o nome de outras mulheres que se movimentaram na esfera pública e que tiveram manifesta influência política no séc. I a. C. A saber: Précia, seguidora de Mário e depois de Sula; Servília, amante de César e mãe do tiranicida Marco Bruto; Hortênsia, filha do famoso orador, que se opôs à imposição de uma taxa especial sobre as mulheres. Sobre estas mulheres, vide também BAUMAN (1992) 65-89. 
do paterfamilias, os papéis tradicionais de cada um dos membros do casal alteravam-se consideravelmente, em especial o da esposa. Perante a situação vulnerável do marido, ela era obrigada a emergir da esfera doméstica e a assumir uma posição de liderança no domínio público, protegendo os bens da família, patrocinando o regresso do marido à pátria e resolvendo todo o tipo de problemas financeiros Esta inversão dos papéis tradicionais fica perfeitamente clara na correspondência que Cícero trocou com a sua amantíssima esposa Terência, como ele lhe chama, durante o seu exílio7.

O casamento de Cícero com Terência durou aproximadamente trinta anos e terá ocorrido por volta do ano 78 a. C. ${ }^{8}$. Em termos afectivos, terá sido este o período em que marido e esposa terão estado mais próximos ${ }^{9}$; as primeiras quatro cartas do Livro XIV, escritas precisamente durante os meses de exílio, denotam o carinho e a cumplicidade que os unia ${ }^{10}$. A elevada pressão psicológica a que então Cícero esteve sujeito induziu-o a expressar na correspondência que com ela trocou o amor, a confiança, o respeito e a admiração que nutria pela mulher ${ }^{11} \mathrm{e}$, em simultâneo, a dar a conhecer alguns dos seus procedimentos em Roma.

Essas quatro missivas não terão sido as únicas enviadas pelo estadista à esposa durante os dezoito longos meses de exílio; ter-se-ão perdido muitas outras, suprimidas, talvez, por serem irrelevantes na perspectiva de quem as divulgou, ou, quiçá, por serem demasiado pessoais ${ }^{12}$. De Terência, não nos chegou nenhuma. Sabemos, no entanto, que escrevia regularmente ao marido, já que muitas das cartas escritas por este mais não são do que respostas ou

${ }^{7}$ Cf. Grebe (2003) 127.

${ }^{8}$ Plutarco não situa cronologicamente a união, referindo-a apenas indirectamente, quando inclui o dote de Terência na lista dos bens de Cícero (cf. Cic. 8.2). Pensa-se, no entanto, que o casamento terá ocorrido no ano 79, ou seja, imediatamente antes da visita de Cícero a Atenas e ao Oriente (cf. Rawson (1975) 25; Shackleton Bailey (1971) 22) ou, então, no ano 77 (cf. Mitchell (1979) 99; Treggiari (1991) 92 sq., nota 44). Vide também Schmidt (1893) 1.175, onde se discute a data em que terá ocorrido o casamento; Drumann-Groebe (1899-1929) v. 6,610 , onde se afirma que a união terá ocorrido por volta do ano 79 e se diz que Cícero teria então vinte e sete anos e a mulher cerca de menos dez que o marido. Terência levou consigo um bom dote, pelo que Cícero terá beneficiado socialmente com a união. Leia-se e.g. o que afirma Treggiari (1991) 92 sq.: «Cicero married the well-born and well-dowered Terentia after his brilliant defence of Roscius in 80 and in good time for his candidacy for the quaestorship in 76 . The first marriage of a bomo nouus, particularly if he won a woman whose family had an assured position in politics, provides the best evidence of how a woman's family might back a potential front-runner.» Cf . Shackleton Bailey (1971) 22. Segundo Gardner (1986) 101, Terência levou consigo «at least 400,00 sesterces cash and some urban real estate which brought in a large income (...)»; segundo CARCopino (1947) 233, «Plutarque, qui arrête à 900.000 sesterces le patrimoine de Cicéron, estime à 1.200 .000 sesterces le douaire de Terentia (...).» Cf. Plu., Cic. 8, 3.

${ }^{9}$ Cf. ClaAssen (1996) 214.

${ }^{10}$ As cartas Fam. 14.1-4 foram escritas entre Abril e Novembro do ano 58 a. C.

${ }^{11}$ Cf. Grebe (2003) 143. Note-se que, nestas circunstâncias, Cícero só tinha vantagens em expressar este tipo de sentimentos e não se podia dar ao luxo de hostilizar, por pouco que fosse, a pessoa que estava a defender os seus interesses.

${ }^{12}$ Cf. Claassen (1996) 214. 
agradecimentos às missivas remetidas pela esposa.

Cícero deixou Roma em Março de 58, antecipando-se, dessa forma, à sua expulsão ${ }^{13}$. Terência poderia ter acompanhado o marido no exílio, mas não o fez. O estadista preferiu que a esposa permanecesse em Roma, acreditando que ela lhe poderia ser muito mais útil aí do que no local onde iria permanecer exilado ${ }^{14}$. Por intermédio de Terência, Cícero poderia «estar presente» na $\operatorname{Vrbs}{ }^{15}$.

No dia do embarque, a 29 de Abril, escreveu a Ático e a Terência cartas reveladoras da dor que então o consumia. As primeiras linhas dirigidas à esposa e aos filhos revelam-nos um homem destroçado e pessimista, que estava a sofrer de forma atroz com a separação imposta da família. Escrevia menos vezes do que aquelas que poderia, porque, de cada vez que o fazia, ou de cada vez que lia as cartas enviadas pela família, rompia em pranto:

Ego minus saepe do ad uos litteras quam possum propterea quod cum omnia mibi tempora sunt misera, tum uero, cum aut scribo ad uos aut uestras lego, conficior lacrimis sic ut ferre non possim. ${ }^{16}$

Escrevo-vos menos vezes do que aquelas que me é possível, porque, como os tempos são para mim de infortúnio, quando vos escrevo ou leio as vossas cartas, sou dominado pelas lágrimas de uma tal maneira que não consigo suportá-lo.

Assumindo-se como responsável pela situação precária e difícil em que então se encontrava, pouco confiante num futuro melhor, esperava que a vida lhe desse, ao menos, a oportunidade de reencontrar a esposa amantíssima (mea uita) para, então, morrer nos seus braços:

Quod utinam minus uitae cupidi fuissemus! Certe nibil aut non multum in uita mali uidissemus. Quod si nos ad aliquam alicuius commodi aliquando reciperandi spem Fortuna reseruauit, minus est erratum a nobis; si<n> haec mala fixa sunt, ego uero te quam primum, mea uita, cupio uidere et in tuo complexu emori, quoniam neque di,

${ }^{13}$ No início de 58, o tribuno da plebe P. Clódio Pulcro, movido por razões de ordem pessoal (Cícero havia testemunhado contra ele no julgamento que o implicava no célebre escândalo da Bona Dea), foi autorizado a condená-lo ao exílio, com a conivência e atitude passiva de Pompeio, apesar de anteriores promessas de amizade e apoio mútuo. Clódio fez afixar um projecto-lei - lex Clodia de capite ciuis Romani - que previa o exílio e a confiscação de bens (aquae et ignis interdictio) para quem tivesse feito executar um cidadão romano sem julgamento prévio. $\mathrm{O}$ visado por esta lei era Cícero, responsável pela morte dos cúmplices de Catilina. Perturbado e numa atitude de desespero, Cícero antecipou o seu exílio, refugiando-se na Grécia. Em resposta a esta sua saída de Roma, Clódio propôs uma segunda lei - lex Clodia de exsilio Ciceronis - que estipulava de forma clara contra o estadista a pena de morte civil, a aquae et ignis interdictio. Conforme se afirma em Oliveira (2005a) 234, «sentindo-se visado pela sua acção contra os adeptos de Catilina, Cícero pretendeu antecipar-se, retirando-se para a Grécia. Mas Clódio, mesmo assim, fez legalizar esse auto-exílio, com consequente destruição da casa do seu inimigo em Roma.»

${ }^{14}$ Cf. Fam. 14.3.5; Q. fr. 1.3.3.

${ }^{15}$ Grebe (2003) 136.

${ }^{16}$ Fam. 14.4.1. 
quos tu castissime coluisti, neque homines, quibus ego semper seruiui, nobis gratiam rettulerunt. ${ }^{17}$

Oxalá me tivesse preocupado menos com a vida! Certamente não teria conhecido as suas agruras, não tantas, pelo menos! Se a Fortuna me preservou para alguma esperança de um dia recuperar alguma felicidade, então é porque o meu erro não foi tão grave. Mas se estas desgraças vieram para ficar, então eu quero ver-te quanto antes, vida minha, e morrer nos teus braços, já que nem os deuses que tu tão piamente honraste, nem os homens a quem eu sempre servi nos recompensaram.

Não concebendo a ideia de viver longe da mulher e, ao mesmo tempo, alimentando a esperança de poder vir a reentrar em Roma, suplicou a Terência que empenhasse todas as suas forças no regresso do marido a casa. Se o seu exílio se prolongasse no tempo, e porque as saudades que sentia já da família eram imensas, esperava que a esposa fosse viver com ele, para ver mitigado o seu sofrimento:

O me perditum, o me adflictum! Quid nunc? Rogem te ut uenias, mulierem aegram, et corpore et animo confectam? Non rogem? Sine te igitur sim? Opinor, sic agam: si est spes nostri reditus, eam confirmes et rem adiuues; sin, ut ego metuo, transactum est, quoquo modo potes, ad me fac uenias. Vnum hoc scito: si te habebo, non mibi uidebor plane perisse. ${ }^{18}$

Oh, que desespero o meu! Oh, que aflição a minha! Que hei-de fazer agora? Pedir-te que venhas, sendo tu uma mulher doente, física e psicologicamente exausta? Não pedir? Terei eu de viver sem ti? Eis o que farei: se existe esperança no meu regresso, peço-te que a reforces e que apoies a minha causa; se, pelo contrário, como temo, tudo estiver decidido, faz o que te for possível para vires ter comigo. Quero que saibas apenas isto: se te tiver junto de mim, não me sentirei totalmente perdido.

Forçado à separação dos filhos, confiou a Terência o futuro de Túlia e de Marco. Emocionou-se ao desejar que o casamento da filha fosse feliz e preservado de desonra ${ }^{19} \mathrm{e}$ ao ansiar poder ter ao seu colo e estreitar nos seus braços o pequeno Marco Cícero, que então contava seis anos:

Sed quid Tulliola mea fiet? Iam id uos uidete; mibi deest consilium. Sed certe, quoquo modo se res habebit, illius misellae et matrimonio et famae seruiendum est. Quid? Cicero meus quid aget? Iste uero sit in sinu semper et complexu tuo. Non queo plura iam scribere; impedit maeror. ${ }^{20}$

\footnotetext{
${ }^{17}$ Ibid..

${ }^{18}$ Fam. 14.4.3.

${ }^{19}$ Túlia havia casado com Pisão Frúgi depois de 63 e, ao que parece, o dote dela ainda não tinha sido pago por inteiro. Cf. Shackleton Bailey (1977) 285 sq., nota 10 ad Fam. 14.4.3.

${ }^{20}$ Fam. 14.4.3. Cf. Fam. 14.1.3.
} 
Mas o que será da minha Tuliazinha? Decide tu, eu nada tenho a sugerir. Uma coisa é certa, independentemente do que vier a acontecer, é imperativo que se preservem o casamento e o bom-nome da pobre pequena. E quanto ao meu filho Cícero? Que fará? Espero que continue sempre abrigado no teu peito e no teu abraço. Não consigo escrever mais; a dor impede-me de continuar.

\section{Preocupava-se igualmente com o futuro de Terência, temendo a confiscação dos seus bens:}

\section{Tu quid egeris nescio, utrum aliquid teneas an, quod metuo, plane sis spoliata. ${ }^{21}$}

Não sei como te tens arranjado; continuas a ter alguns bens na tua posse, ou, tal como receio, foste espoliada de tudo?

Durante o exílio, como em muitas outras ocasiões, Terência actuou como agente do marido, cuidando dos interesses dele em Roma. Pouco tempo depois da partida do estadista, a esposa manifestou alguma preocupação com a possibilidade de ele vir a conceder a manumissio aos escravos que eram pertença da família. O marido, no intuito de a tranquilizar, assegurou-lhe que ela poderia decidir o destino dos seus próprios escravos ${ }^{22}$. Aos dele, em caso de confiscação dos seus bens, deveria conceder-se a manumissão. $\mathrm{Na}$ eventualidade de este cenário não se confirmar, esses escravos, à excepção de um pequeno número, permaneceriam sua propriedade:

De familia liberata, nibil est quod te moueat. Primum tuis ita promissum est, te facturam esse ut quisque esset meritus; (...) Ceterorum seruorum ea causa est ut, si res a nobis abisset, liberti nostri essent, si obtinere potuissent; sin ad nos pertinerent, seruirent praeterquam oppido pauci. ${ }^{23}$

Quanto à manumissão dos escravos, não há motivo para te preocupares. Em primeiro lugar, foi prometido aos teus que irias ter em conta o mérito de cada um. (...) A situação dos outros escravos é a seguinte: se os meus bens deixassem de me pertencer, eles seriam os meus libertos, caso eles conseguissem fazer valer esse estatuto; se, pelo contrário, continuassem a ser minha propriedade, permaneceriam meus escravos, à excepção de um pequeno número.

A manumissio permitir-lhe-ia, assim, furtar-se, pelo menos parcialmente, às consequências de uma confiscação, não o obrigando a uma perda total dos seus bens; se a manumissão precedesse a confiscação, os escravos libertos não

${ }^{21}$ Fam. 14.4.4.

${ }^{22}$ TREGGIARI (1991) 326 comenta desta forma a atitude de Cícero: "In the crisis of 58, when Cicero was at least thinking of manumitting slaves in case his property was confiscated, he assures Terentia that he had only told her slaves that she would act in accordance with the deserts of each of them. Since he could not manumit slaves who were her private property, it sounds very much as if he must mean dotal slaves. Although the formal manumission would need to come from him, he implies the decision would be hers."

${ }^{23}$ Fam. 14.4.4. 


\section{poderiam ser incluídos no inventário dos bens a leiloar em hasta pública ${ }^{24}$.} Mas não era apenas na resolução de questões de natureza prática que Terência apoiava Cícero. Apesar de distante fisicamente, ela não deixava de o exortar a ser corajoso e a manter a esperança na chegada de dias melhores. A força do seu carácter contrastava com a vulnerabilidade emocional em que o marido havia caído:

${ }^{24}$ Segundo Shackleton Baily (1977) 286, nota 7 ad Fam. 14.4.4, os bens pessoais de Cícero seriam vendidos sub hasta, mas poderiam ser adquiridos por alguém da sua confiança (como Ático, por exemplo) que, desse modo, evitaria que ele os perdesse irrevogavelmente. Cícero parece ter decidido conceder a manumissão aos seus escravos inter amicos, isto é, informalmente, ciente de que a manumissão (que, sendo informal, podia ser revogada por ele), em última instância, não se confirmaria, a não ser para alguns. Se, por outro lado, os seus bens fossem mesmo alienados, os escravos poderiam reclamar o estatuto de libertos, embora Cícero duvidasse da legitimidade dessa reclamação. Como afirma Dixon (1984) 80 sq., a discussão de questões como esta na correspondência de Cícero lança alguma luz sobre a distribuição e administração dos bens dentro do casamento. Segundo a autora, Cícero deveria ser o dono dos escravos. Todavia, neste passo, fez distinção entre os de Terência (tui) e os seus (nos, nostri). Terência poderia decidir o destino dos escravos dela, optando ou não por adoptar a medida de precaução que constituía a manumissio. Aos de Cícero, porém, poderia vir a ser necessário conceder o estatuto de liberti. Os escravos que Cícero designou tui eram, pensa-se, parte do dos de Terência. De acordo com a lei, um marido romano (ou o paterfamilias), ao receber a esposa, tornava-se imediatamente dono do dos que ela levava consigo para o casamento. Era este o status quo, mesmo depois da instituição, no tempo de Augusto, das limitações ao direito do marido de alienar ou hipotecar terreno dotal (Cf. Gaius, Inst. 2.63: Nam dotale praedium maritus inuita muliere per legem Iuliam probibetur alienare, quamuis ipsius sit uel mancipatum ei dotis causa uel in iure cessum uel usucaptum. quod quidem ius utrum ad Italica tantum praedia an etiam ad prouincialia pertineat, dubitatur.). Neste sentido, o dote poderia ser incluído numa lista oficial dos seus pertences, mas, já que, na sua essência, era passível de ser devolvido, era habitual o marido referir-se-lhe, de forma vaga, como sendo pertença da mulher (cf. Plb. 31.27.4). Não é claro se Cícero se estava a referir à manumissio como um facto cumprido ou como uma possibilidade que ele encarava: a expressão de familia liberata poderia ser condicional ou significar apenas «quanto à questão de emancipar os escravos» (cf. Dixon (1984) 81; vide ainda SHackleton Bailey (1977) 286, nota 3 ad loc.: «Cicero (...) is speaking from his wife's standpoint; she thought there had been a general manumission.»). De qualquer forma, Cícero poderia emancipar escravos de Terência, na qualidade de dono, somente se os bens em questão fizessem parte do dote dela. Ele não poderia dar ou ter em consideração esse passo se eles pertencessem à esposa no sentido legal, e o texto, tal como se apresenta, estaria assim a induzir em erro. Significa isto que a esposa poderia perder o dote 'dela' se os bens do marido fossem confiscados? Esta questão tem sido muito debatida. Diversos estudiosos têm proposto diferentes soluções ao longo dos séculos uns defendendo que o dote era normalmente excluído da confiscação, outros que era incluído. Não existem certezas quanto a esta questão. Para Cícero, o que importava verdadeiramente é que a confiscação do dote de Terência era uma possibilidade. Jurista experimentado e conhecedor do poder e da sede de vingança de Clódio, desejava tranquilizar a esposa quanto aos escravos que faziam parte do seu dote, assegurando-lhe que os bens não estavam irremediavelmente perdidos. Achava, como administrador do dote, que lhe devia uma explicação. Mesmo que o dos de Terência pudesse ser confiscado com os seus bens, Cícero considerava-se responsável perante a esposa pela administração que dele fizesse. Acreditava, porém, que, se tudo corresse bem, poderia preservar o dos da esposa, mesmo que os seus próprios bens viessem a ser alvo de confiscação. Apesar de, em alguns momentos, poder ter receado que os bens dela estivessem em risco, no fundo, tinha esperanças de que o pior não viesse a acontecer, já que os bens dela eram legalmente distintos dos seus. Cf. Dixon (1984) 80-82. 
Tu quod me hortaris ut animo sim magno et spem habeam recuperandae salutis, id uelim sit eius modi ut recte sperare possimus. ${ }^{25}$

Tu exortas-me a que me mantenha bastante animado e confiante na recuperação da minha integridade; gostaria que houvesse maneira de poder aspirar verdadeiramente a isso.

Depois de retribuir o apoio moral dado por Terência ${ }^{26}$, Cícero despediu-se emocionado da esposa e dos filhos, dirigindo-lhes, individualmente, palavras carinhosas e encomiásticas, comprovativas do afecto que a todos unia:

Cura, quod potes, ut ualeas et sic existimes, me uehementius tua miseria quam mea commoueri. Mea Terentia, fidissima atque optima uxor, et mea carissima filiola et spes reliqua nostra, Cicero, ualete. ${ }^{27}$

Cuida, na medida do que te é possível, da tua saúde, e acredita que o teu infortúnio me comove mais do que o meu. Minha Terência, a mais fiel e a melhor das esposas, minha muito querida filhinha, e (Marco) Cícero, nossa última esperança, adeus.

Cerca de cinco meses depois ${ }^{28}$, as saudades da família eram tais que, quando tentava escrever-lhe algumas palavras, rompia em lágrimas abundantes, culpando-se pela situação difícil em que tinha deixado a esposa e a filha:

Ad te uero et ad nostram Tulliolam non queo sine plurimis lacrimis scribere. Vos enim uideo esse miserrimas, quas ego beatissimas semper esse uolui idque praestare debui, et, nisi tam timidi fuissemus, praestitissem. ${ }^{29}$

Não consigo escrever-te a ti e à nossa Tuliazinha sem chorar copiosas lágrimas. De facto, vejo que se encontram muito infelizes, vocês que eu sempre quis que fossem muito felizes e a quem eu deveria ter garantido a felicidade - e teria, se não tivesse sido tão cobarde.

Para ilustrar o seu sentimento de culpa, Cícero referiu, depois, um incidente que envolveu a esposa e que lhe causou grande tristeza e frustração. De acordo com o que o amigo P. Valério lhe narrara, Terência teria sido arrastada à força

${ }^{25}$ Fam. 14.4.5.

${ }^{26}$ Fam. 14.4.6: Quod reliquum est, sustenta te, mea Terentia, ut potes honestissime.

${ }^{27} \mathrm{Fam}$. 14.4.6. O recurso a adjectivos no grau superlativo para referir os membros da família denota o amor e a admiração que Cícero nutria pelos seus, nesta situação de carência afectiva. Cf. Fam. 14.3.2.

${ }^{28}$ Mais precisamente, a 5 de Outubro de 58.

${ }^{29}$ Fam. 14.2.1. Note-se a utilização dos superlativos de sentido antitético (miserrimas/ beatissimas), reveladora de quão dilacerada se encontrava a alma do remetente da carta. Cf. Fam. 14.1.1; 14.3.1. 
desde o Templo de Vesta ${ }^{30}$ até à Tabula Valeria ${ }^{31}$ e sujeita a alguma forma de humilhação pública, possivelmente devido às suas diligências em favor do marido ausente ${ }^{32}$. Cícero recriminou-se amargamente por este incidente; em vez de ser motivo de honra para Terência e para os filhos, apenas lhes trouxera desonra $^{33}$. O incidente da Tabula Valeria fê-lo culpar-se:

A te quidem omnia fieri fortissime et amantissime uideo, nec miror, sed maereo casum eius modi ut tantis tuis miseriis meae miseriae subleuentur. Nam ad me P. Valerius, bomo officiosus, scripsit, id quod ego maximo cum fletu legi, quem ad modum a Vestae ad Tabulam Valeriam ducta esses. Hem, mea lux, meum desiderium, unde omnes opem petere solebant, te nunc, mea Terentia, sic uexari, sic iacere in lacrimis et sordibus, idque fieri mea culpa, qui ceteros seruaui ut nos periremus. ${ }^{34}$

Vejo que fazes tudo com muita coragem e muito amor, e isso não me surpreende, mas dói-me muito que os meus infortúnios sejam atenuados à custa do teu infortúnio. P. Valério, homem dedicado, contou-me - o que me fez chorar muito quando li - como foste conduzida do Templo de Vesta até à Tabula Valeria. Ah, luz da minha vida, meu amor, a quem todos costumavam pedir ajuda, e agora, querida Terência, vexada desta maneira, mergulhada em lágrimas e na desonra, e é por minha culpa que isso acontece, que preservei outros para nos levar à ruína!

$\mathrm{Na}$ sequência do seu exílio, Cícero acabou por perder a casa. A integridade do dote de Terência, cuja administração era da responsabilidade do marido, poderá ter estado também em risco - ainda que ele tenha tentado protegê-lo da confiscação -, mas os bens pessoais da esposa, ao que parece, terão permanecido intactos, e Cícero considerava que assim deveriam permanecer. Quando soube que ela andava a gastar os seus rendimentos pessoais em prol da causa do marido, não conseguiu deixar de admoestá-la por isso:

Quod de domo scribis, hoc est de area, ego uero tum denique mibi uidebor restitutus, si illa nobis erit restituta. Verum haec non sunt in nostra manu; illud doleo, quae

${ }^{30}$ A sua meia-irmã, Fábia, era sacerdotisa neste templo: Asc., Tog. 91. Segundo SHackleton BAiley (1977) 287, nota 9 ad loc., Terência poderá ter ido ao templo em busca de refúgio.

${ }^{31}$ Cf. Cic. Sest. 69: euersa domus est. Fortunae uexatae, dissipati liberi, raptata coniux.

${ }^{32} \mathrm{O}$ incidente tem sido interpretado de formas diversas. Shackleton Bailey (1977) 287 sq., nota 9 ad loc., advoga que Terência foi levada à presença dos tribunos, que se costumavam reunir junto a um fresco conhecido por Tabula Valeria; por sua vez, Constans (1935) 17 e nota 1, sustenta que a Tabula Valeria seria um banco. Segundo Shackleton Bailey (1977) 288, nota 9 ad Fam. 14.2.2, este infeliz incidente prendeu-se com questões financeiras e terá sido perpetrado por Clódio ou qualquer outro inimigo de Cícero. Na sua edição mais recente (cf. (2001) nota 1 ad loc.), reafirma que o incidente teve lugar «in the Comitium, called after a painting set up by M. Valerius Messala (nothing to do with P. Valerius) to commemorate a victory in the first Punic War.» Acrescentou ainda que «the Tribunes met there officially and it seems that Terentia had been summoned before them in connection with financial matter. Her half-sister Fabia was a Vestal Virgin.»

${ }^{33}$ Cf. e.g. Fam. 14.4.3; 14.3.2.

${ }^{34}$ Fam. 14.2.2. 
impensa facienda est, in eius partem te miseram et despoliatam uenire. ${ }^{35}$

Quanto ao que escreves sobre a nossa casa, ou melhor, sobre o sítio dela, de facto, não me sentirei verdadeiramente ressarcido enquanto aquela não me for devolvida. Mas estas coisas não estão na nossa mão. O que me dói é que tu, infeliz e espoliada, estejas a contribuir para as despesas que é necessário fazer.

Pediu-lhe, então, que deixasse os amigos suportarem quaisquer despesas desse tipo, porque, no caso de se dar o pior, iriam precisar dos bens dela para assegurar o futuro:

Quod si conficitur negotium, omnia consequemur; sin eadem nos fortuna premet, etiamne reliquias tuas miseras proicies? Obsecro te, mea uita, quod ad sumptum attinet, sine alios, qui possunt si modo uolunt, sustinere; et ualetudinem istam infirmam, si me amas, noli uexare. ${ }^{36}$

Se a coisa se concretizar, conseguiremos tudo; mas, se pelo contrário, continuar a perseguir-me a mesma Fortuna, vais deitar fora as poucas coisas que te restam? Suplico-te, vida minha, no que concerne a despesas, deixa que outros que podem, se quiserem, as suportem; e não queiras, se me amas, prejudicar a tua débil saúde.

Estava, portanto, preocupado com as finanças familiares, mas também com a saúde infirma da esposa. Aliás, segundo as suas palavras, e com evidente exagero interesseiro, Terência dominava dia e noite os seus pensamentos; a frágil condição física da esposa era fonte de preocupação, já que via recaírem sobre os ombros dela inúmeras responsabilidades:

Nam mibi ante oculos dies noctesque uersaris. Omnis labores te excipere uideo; timeo ut sustineas, sed uideo in te esse omnia. Quare, ut id quod speras et quod agis consequamur, serui ualetudini. ${ }^{37}$

$\mathrm{Na}$ verdade, resides dia e noite diante dos meus olhos. Vejo que carregas todos os fardos. Temo que não resistas, mas vejo que tudo recai sobre ti. Por isso, para que possamos alcançar aquilo por que anseias e lutas, cuida bem da tua saúde.

Atendendo ao desejo por ela expresso de que se não afastasse ainda mais de Roma, decidiu não ir além de Tessalonica. Antes de se despedir com carinho, pediu-lhe que lhe escrevesse com mais frequência, sobretudo se houvesse motivo de esperança no seu regresso a casa:

${ }^{35}$ Fam. 14.2.3. Cf. Att. 3.15.6, de17 de Agosto: Quid de bonis? Quid de domo? Poteritne restitui? Aut si non poterit egomet quo modo potero?

${ }^{36}$ Fam. 14.2.3.

${ }^{37}$ Fam. 14.2.3. Cf. Fam. 14.3.2. 
Longius, quoniam ita uobis placet, non discedam; sed uelim quam saepissime litteras mittatis, praesertim si quid est firmius quod speremus. Valete, mea desideria, ualete. $^{38}$

Já que é esse o vosso desejo, não irei para mais longe. Gostaria, no entanto, que vocês me escrevessem o mais frequentemente possível, sobretudo se houver algo que confirme as nossas esperanças. Adeus, meu amor, adeus.

Era fundamental, por conseguinte, que Terência o mantivesse devidamente informado sobre tudo o que se passava em Roma; isso ajudá-lo-ia a manter-se vivo ${ }^{39}$.

A 25 de Novembro, voltou a escrever aos seus. A carta abria com rasgados elogios à força de carácter e à coragem demonstradas por Terência nos últimos tempos ${ }^{40}$. Todos reconheciam que a esposa conduzia de forma admiravelmente incansável os destinos da família:

Et litteris multorum et sermone omnium perfertur ad me incredibilem tuam uirtutem et fortitudinem esse teque nec animi neque corporis laboribus defatigari. ${ }^{41}$

Sei, tanto pelas cartas de muitos que me escrevem, como pelo que me dizem os que comigo conversam, que a tua virtude e a tua coragem são incríveis, e que não te deixas abater pelas provações físicas e morais a que tens sido sujeita.

Elogiando as admiráveis uirtus, fortitudo, fides, probitas e bumanitas de Terência, sentia-se culpado pela desgraça em que lançara a esposa virtuosa e a que submetera os filhos, Túlia e Marco, quando decidiu dar ouvidos a quem lhe queria mal e desprezar os conselhos dos amigos verdadeiros:

Me miserum! Te ista uirtute, fide, probitate, bumanitate in tantas aerumnas propter me incidisse, Tulliolamque nostram, ex quo patre tantas uoluptates capiebat, ex eo tantos percipere luctus! Nam quid ego de Cicerone dicam? Qui cum primum sapere coepit, acerbissimos dolores miseriasque percepit. Quae si, tu ut scribis, fato facta putarem, ferrem paulo facilius; sed omnia sunt mea culpa commissa, qui ab iis me amari putabam qui inuidebant, eos non sequebar qui petebant. Quod si nostris consiliis usi essemus neque apud nos tantum ualuisset sermo aut stultorum amicorum aut improborum, beatissimi uiueremus. ${ }^{42}$

Como sou infeliz! Pensar que a minha virtuosa, leal, honesta e gentil esposa caiu em tão grandes desgraças por minha causa! E pensar que a nossa pequena Túlia está a sofrer tão grande dor por causa do pai que lhe dava tão grandes alegrias! E do (Marco) Cícero, que hei-de eu dizer, que logo que começou a

${ }^{38}$ Fam. 14.2.4.

39 Terência escrevia regularmente ao marido a informá-lo de tudo o que se passava: Fam. 14.1.3; 14.1.5; 14.2.3; 14.3.3.; 14.4.4. Cf. Fam. 14.3.4; 14.3.5; 14.4.5.

${ }^{40} \mathrm{Em}$ cartas dirigidas a outras pessoas, Cícero referiu-se à esposa com grande respeito e carinho. Terência era, nas suas palavras, uma esposa fiel e desafortunada, que tinha de suportar mais do que qualquer mulher alguma vez suportara. Cf. Q. fr. 1.3.3; Att. 3.19.2; 3.23.5.

${ }^{41}$ Fam. 14.1.1.

${ }^{42}$ Fam. 14.1.1-2. Cf. Fam. 14.2.1; 14.3.1. 
perceber as coisas experimentou amarga dor e desgraça? Se eu pensasse, como escreves, que isto é obra do destino, suportá-lo-ia um pouco mais facilmente. Mas a culpa de tudo é minha, que pensava ser amado por pessoas que me invejavam e recusava seguir os que me queriam. Se tivesse confiado no meu pensamento em vez de dar tanta importância à conversa dos amigos estúpidos e pérfidos, viveria muito feliz!

Mas já que os amigos o levavam a ter esperança no regresso a casa, prometeu a Terência que não se iria entregar ao pessimismo; não queria deitar por terra todos os esforços por ela empreendidos até então:

Nunc, quoniam sperare nos amici iubent, dabo operam ne mea ualetudo tuo labori desit. ${ }^{43}$

Agora, já que os nossos amigos nos dizem para termos esperança, farei por que o meu estado de saúde não torne inúteis os teus esforços.

Saudoso, ansiava pelo dia em que lhe seria permitido voltar a abraçar a família, como recompensa do amor que a todos unia:

Quem ego diem si uidero et si in uestrum complexum uenero ac si et uos et me ipsum reciperaro, satis magnum mibi fructum uidebor percepisse et uestrae pietatis et meae. ${ }^{44}$

Se eu chegar a ver esse dia e voltar a encontrar-me nos vossos braços, se vos receber de volta e a mim próprio, tal será para mim uma recompensa suficientemente grande da tua dedicação e da minha.

Discutiu novamente com Terência assuntos relacionados com a gestão financeira familiar, como a manumissio estratégica dos seus escravos ${ }^{45}$, ou a venda que a esposa decidira fazer, contra a vontade do marido, de alguns dos seus bens pessoais (um bloco de casas: uicum), para fazer face a despesas:

Quodad me, mea Terentia, scribis te uicumuendituram, quid, obsecrote (me miserum!), quid futurum est? Et si nos premet eadem fortuna, quid puero misero fiet? ${ }^{26}$

Escreves-me, minha querida Terência, que vais vender um grupo de casas. Diz-me - que infortúnio o meu! - o que vai acontecer? E se o mesmo azar continuar a perseguir-nos, que será do nosso pobre menino?

Cícero estava preocupado com o destino do filho. Insistiu, por isso, que Terência, em vez de se desfazer dos seus próprios bens, recorresse à ajuda dos amigos, porque, se acontecesse o pior, iriam precisar dos bens dela para

\footnotetext{
${ }^{43}$ Fam. 14.1.2.

${ }^{44}$ Fam. 14.1.3. Cf. Fam. 14.4.3.

${ }^{45}$ Fam. 14.1.3: De familia quomodo placuisse scribis amicis faciemus. Cf. 14.4.4.

${ }^{46}$ Fam. 14.1.4.
} 
garantir o bem-estar do pequeno Marco. Advertiu a esposa de que poderia estar a empenhar o futuro do jovem, se continuasse a gastar, sem cuidado, a sua fortuna pessoal ${ }^{47}$ :

${ }^{47}$ Como afirmam Garnsey-SAller (1987) 130, em termos legais, «the conjugal couple was not one financial entity, but two, with the wife enjoying complete legal independence in the ownership of property after her father's death.» Segundo Dixon (1984) 83, porém, a separação de bens dos cônjuges não implicava uma separação de interesses: «Terentia shared Cicero’s assumption of her devotion to his cause and the availability of her fortune to their children in case of need.» Nesta altura, o pai de Terência já não se encontraria vivo, pelo que ela seria uma mulher sui iuris - portanto, tecnicamente sujeita às limitações da tutela mulierum. Originalmente, a função do tutor (ou tutores) consistia em guardar os bens da pessoa que estava sob a sua tutela, que havia sido instituída para protecção dos interesses da família. Paulatinamente, porém, a aparentemente restritiva tutela mulierum do período da Lei das XII Tábuas degenerou, no século II, numa mera sombra do que fora na sua origem. Assim, em pleno século I, mesmo que as transacções de Terência fossem feitas com base no pressuposto de que a sanção do seu tutor poderia ser tomada como certa, a venda de bens, tal como a decisão relativa à forma como deveria usar os seus rendimentos eram essencialmente da sua competência. $\mathrm{O}$ argumento apresentado por Cícero de que a fortuna dela poderia, no futuro, ser necessária para o sustento dos filhos sugere a persistência da noção de que os bens funcionavam de alguma forma como um seguro familiar a ser utilizado através das gerações, mas a «família» que ele invoca não corresponde à rede agnática em que assentara a instituição da tutela na sua fundação (Gaius, Inst. 1.155 sqq. e 165). Quer o tutor de Terência fosse um parente próximo - tutor agnatus - , quer fosse um amigo da família ou um dependente (tutor extraneus), «her fortune was seen as hers to disburse and as destined for her children rather than her agnates.» Uma mulher sui iuris, como Terência, podia, neste período da vida, caso assim o entendesse, dispor livremente dos seus próprios bens. Estes não eram propriedade masculina - como eram quando a mulher se encontrava in manu mariti (Cic., Top. 23: Cum mulier uiro in manum conuenit, omnia quae mulieris fuerunt uiri fiunt dotis nomine; Gaius, Inst. 2.96: In summa sciendum est his, qui in potestate manu mancipioue sunt, nibil in iure cedi posse; cum enim istarum personarum nibil suum esse possit, conueniens est scilicet, ut nibil suum esse in iure uindicare possint; 139: Idem iuris est, si cui post factum testamentum uxor in manum conueniat, uel quae in manu fuit, nubat: nam eo modo filiae loco esse incipit et quasi sua) - nem estavam sob efectiva supervisão masculina. Ela detinha e administrava de pleno direito o património pessoal. No caso de uma mulher madura sui iuris, como Terência, a contribuição para o lar matrimonial e para o sustento dos filhos terminaria, legalmente, com o pagamento final do dote. Não obstante, os dois cônjuges encaravam como natural a possibilidade de ela assumir, em circunstâncias especiais, a responsabilidade pelo futuro do jovem Marco. Cf. Dixon (1984) 84 sq. Durante o exílio, Cícero recomendou a família a Quinto, confiando que os filhos nunca poderiam ser verdadeiramente órfãos enquanto o tio paterno estivesse são e salvo (cf. Q.fr. 1.3.10). Esta commendatio tinha um alcance generalizante: os homens recomendavam as esposas e os filhos ao cuidado de amigos sempre que a sua vida corria perigo ou deixavam Roma numa viagem de rotina. A recomendação não implicava, todavia, que esses amigos assumissem o total apoio financeiro das pessoas recomendadas (compare-se, todavia, a commendatio de Túlia, feita por Cícero, a Ático, em Janeiro de 47, quando o pai pediu ao amigo que prestasse apoio financeiro à filha, prevendo que a mãe, como ele, iria ser espoliada dos seus bens, cf. Att. 11.9.3: Alium enim cui illam commendem habeo neminem, Quoniam matri quoque eadem intellexi esse parata quae mibi. Sed si me non offendes, satis tamen habeto commendatam patruumque in eam quantum poteris mitigato). Das cartas do exílio transparece, no entanto, a ideia de que Cícero esperava ser mantido pelo irmão, caso viesse a ser despojado dos seus bens, enquanto os filhos recorreriam à mãe. Esta cadeia variegada de obrigações familiares não coincide exactamente com a moldura legal segundo a qual somente por morte intestada da mãe os filhos teriam o direito remoto de cognati sobre os bens dela. Cícero esperava que Terência prestasse apoio financeiro aos filhos, como se ela, mais do que o tio paterno, Quinto (que era parente próximo por agnação), fosse o recurso óbvio de Túlia e de Marco em momentos de aflição: «Thus, even in an emergency, when 
Non queo reliqua scribere, tanta uis lacrimarum est; neque te in eundem fletum adducam. Tantum scribo: si erunt in officio amici, pecunia non deerit; si non erunt, tu efficere tua pecunia non poteris. Per fortunas miseras nostras, uide ne puerum perditum perdamus. Cui si aliquid erit ne egeat, mediocri uirtute opus est et mediocri fortuna ut cetera consequatur. ${ }^{48}$

Não consigo escrever o resto, tamanha é a força das lágrimas, e eu não vou levarte ao mesmo pranto. Escrevo tão-somente: se os nossos amigos cumprirem o seu dever, não faltará dinheiro; se não cumprirem, não poderás obter resultados com o teu dinheiro. Em nome da nossa triste sorte, não deixes que levemos o nosso pobre pequeno à ruína. Se ele tiver algo que o impeça de passar necessidades, bastar-lhe-á apenas um pouco de coragem e um pouco de sorte para alcançar tudo o resto.

A obrigação, assumida por Cícero, de que Terência deveria velar pelo futuro do filho ultrapassava aquilo a que o direito familiar obrigava. Segundo a lei, em caso de necessidade, os filhos de Cícero deveriam ser sustentados pelo tio paterno, que era seu parente agnato (isto é, com eles mantinha laços de sangue por via paterna). O pai, porém, atribuía essa obrigação à esposa, esperando que ela assumisse, no campo financeiro, o papel do irmão dele. Ao assumir como sua essa obrigação, Terência insinuava-se, uma vez mais, no campo da autoridade masculina ${ }^{49}$.

A condição social de Terência estava intimamente ligada à do marido e a ruína de Cícero poderia prejudicar o seu status. O casal, porém, estava longe de ser perspectivado como uma unidade económica. Os bens do casal encontravam-se tão claramente divididos que Cícero não tinha poder de controlo sobre as transacções financeiras da esposa. A insistência para que ela deixasse outros assumirem as despesas não fora atendida; Terência assumia-se, afinal, uma mulher com alguma autonomia financeira ${ }^{50}$.

O sentimento de culpa em relação à situação em que deixara a família era um tormento constante. Na carta que escreveu a 29 de Novembro, reconhecendo embora a intensidade do sof rimento da esposa e dos filhos, afirmou ser maior a sua desgraça, já que sua era a culpa de toda a situação:

all family elements rallied around, the financial separate-ness of the spouses was maintained much as the law required, but the maternal-child links apparently exceeded any legal definition of obligation.» Dixon (1984) 86 sq.

${ }^{48}$ Fam. 14.1.5.

${ }^{49}$ Cf. Grebe (2003) 138.

${ }^{50} \mathrm{Cf}$. Dixon (1984) 83. Terência não se considerava obrigada a dar contas a Cícero do uso que fazia dos seus próprios bens, ainda que com ele partilhasse a ideia de que, em situações de emergência, deveria garantir o sustento dos filhos; como esposa e como mãe, ela estava sensibilizada e preparada para ajudar a sua família matrimonial e - se necessário - para usar a fortuna pessoal em benefício dela, mas não para abdicar do seu direito de decidir sobre a melhor forma de demonstrar a sua lealdade para com a família: «She was apparently unhampered by the restrictions of tutela mulierum in her commercial transactions and proceeded on the assumption that her activities would be routinely authorized.» Dixon (1984) 87. 
Conficior enim maerore, mea Terentia, nec meae me miseriae magis excruciant quam tuae uestraeque. Ego autem hoc miserior sum quam tu, quae es miserrima, quod ipsa calamitas communis est utriusque nostrum, sed culpa mea propria est. ${ }^{51}$

Estou dominado pela dor, querida Terência, e o meu infortúnio não me tortura mais do que o teu, do que o vosso. Eu, porém sou mais infeliz do que tu, que és infelicíssima, porque a desgraça é comum a ambos, mas a culpa é somente minha.

Além de culpado, sentia-se envergonhado ${ }^{52}$. Não conseguia deixar de pensar na aflição por que estavam a passar os filhos e a esposa ${ }^{53}$. Não desistiria, porém, de lutar, pelo menos enquanto sentisse que a família mantinha acesa a chama da esperança:

Spes autem salutis pertenuis ostenditur. Inimici sunt multi, inuidi paene omnes. Eicere nos magnum fuit, excludere facile est. Sed tamen, quam diu uos eritis in spe, non deficiam, ne omnia mea culpa cecidisse videantur. ${ }^{54}$

A esperança de salvação afigura-se muito ténue. São muitos os meus inimigos, quase todos me invejam. Foi tarefa difícil desterrar-me, mas manter-me longe é fácil. Enquanto, porém, vocês mantiverem a esperança, não me deixarei vencer, para não ser considerado culpado de todos os fracassos.

A esposa do orador empenhou-se no regresso e na segurança dele enquanto exilado ${ }^{55}$, e exerceu - como o fez, aliás, durante todo o tempo em que estiveram casados - um forte ascendente sobre o marido, influenciando a sua tomada de decisões na esfera política e privada:

Ego tamen faciam quae praecipis. Amicis quibus uoluisti egi gratias et eas litteras Dexippo dedi meque de eorum officio scripsi a te certiorem esse factum. ${ }^{56}$

Farei, todavia, o que me aconselhas. Agradeci aos amigos a quem querias que agradecesse e entreguei as cartas a Dexipo; escrevi que foste tu quem me informou dos bons serviços por eles prestados.

${ }^{51}$ Fam. 14.3.1. Cf. 14.2.1 e 14.1.1.

${ }^{52}$ Fam. 14.3.2: Qua re cum dolore conficiar, tum etiam pudore. Pudet enim me uxori [mea] optimae, suauissimis liberis uirtutem et diligentiam non praestitisse. Note-se, mais uma vez, o recurso a termos superlativos para referir os membros da família. Como refere Treggiari (1998) 12 , «he [Cícero] makes it clear that his duty included a duty to look after his family. He is ashamed that he has not shown courage and proper care (diligentia) to his excellent wife and adorable children. It is his fault they are suffering.» Cf. Fam. 14.4.6.

${ }^{53}$ Fam. 14.3.2: Nam mi ante oculos dies noctesque uersatur squalor uester et maeror et infirmitas ualetudinis tuae. Cf. Fam. 14.2.3.

${ }^{54}$ Fam. 14.3.2.

${ }^{55}$ Fam. 14.3.3: Vt tuto sim quod laboras...

${ }^{56}$ Fam. 14.3.3. Cf. $§ 5:$ Ex primis aut summum secundis litteris tuis constituere poterimus quid nobis faciendum sit. 
Cícero aceitava, portanto, as sugestões e conselhos da esposa. Ela mantinha-o informado de todos os desenvolvimentos relativos à sua situação política. Era este o desejo do marido:

Ea re ad te statim Aristocritum misi ut ad me continuo initia rerum et rationem totius negoti posses scribere. ${ }^{57}$

Foi por isso que te enviei imediatamente Aristócrito, para que possas relatar-me sem demora o início das coisas e o desenvolvimento de toda esta questão.

Terência tinha sobre os seus ombros a difícil tarefa de conseguir que o marido fosse resgatado do exílio. Ele próprio reconhecia a importância do papel desempenhado pela esposa, pedindo-lhe que ficasse em Roma a tomar as diligências necessárias à sua reentrada na Urbe, ao invés de se lhe juntar, como chegara a sugerir. Se tudo corresse bem, acabaria ele por se juntar à família:

Quod scribis te, si uelim, ad me uenturam, ego uero, cum sciam magnam partem istius oneris abs te sustineri, te istic esse uolo. Si perficitis quod agitis, me ad uos uenire oportet. ${ }^{58}$

Quanto à possibilidade de vires, se eu quiser, ao meu encontro, na verdade, como sei que grande parte deste fardo recai sobre os teus ombros, quero que te mantenhas aí. Se vocês forem bem sucedidos nos vossos esforços, sou eu quem deve ir ao vosso encontro.

Ao que tudo indica, a esposa fiel, com a ajuda de amigos próximos da família e eventualmente do cunhado Quinto Cícero, tudo estaria a fazer no sentido de conseguir o perdão para o marido. Não admira, pois, que, a fechar esta última carta, em jeito de agradecimento à esposa dedicada, que considerava o seu maior tesouro, Cícero tenha pronunciado esta emocionada jura de amor, claramente influenciada pelo tempo de separação:

Cura ut ualeas et ita tibi persuadeas, mibi te carius nibil esse nec umquam fuisse. Vale, mea Terentia; quam ego uidere uideor itaque debilitor lacrimis. Vale. ${ }^{59}$

Cuida da tua saúde, e acredita que para mim não existe, nem nunca existiu, nada mais importante do que tu. Adeus, minha querida Terência. Parece que te estou a ver, e assim desfaço-me em lágrimas. Adeus.

São significativos, e curiosos, os dados que aproximam os percursos trilhados por Cícero e Ovídio. O poeta de Sulmona nasceu precisamente no mesmo ano em que o orador foi assassinado (43 a. C.). No ano $8 \mathrm{~d}$. C., também ele foi obrigado

\footnotetext{
${ }^{57}$ Fam. 14.3.4. Cf. § 5: Tu modo ad me uelim omnia diligentissime perscribas...

${ }^{58}$ Fam. 14.3.5.

${ }^{59}$ Ibid.
} 
a deixar a pátria e a sofrer as agruras de uma separação imposta da família ${ }^{60}$ - à semelhança do que aconteceu a Cícero, em pleno auge da sua carreira ${ }^{61}$ e quando contava meio século de existência ${ }^{62}$. Para manter o contacto com a Urbe, os amigos e a esposa, também ele elegeu a escrita como meio de comunicação. Um pouco à semelhança de algumas cartas de Cícero, mas de uma maneira mais formal, os Tristia e, mais tarde, as Epistulae ex Ponto funcionaram como cartas abertas por meio das quais o poeta, à distância, esperava ver reconsiderada a sua sentença. Tal como o Arpinate, também Ovídio dedicou aos amigos e à esposa parte dos seus escritos do tempo em que esteve fora de Roma. Existirão, porém, semelhanças entre o papel assumido pela esposa do Sulmonense durante a ausência do marido em Tomos e aquele que havia sido assumido meio século antes por Terência? Analisemos a importância e o âmbito de influência da uxor de Ovídio aquando da relegatio do marido, tendo como base os textos por ele escritos.

O momento da partida de um condenado ao 'exílio' é sempre dramático. A despedida de Ovídio dos amigos e da sua terceira esposa ${ }^{63}$ não foi excepção:

Vt tamen banc animi nubem dolor ipse remouit

Et tandem sensus conlualuere mei,

Adloquor extremum maestos abituros amicos,

Qui modo de multis unus et alter erat.

$V x o r$ amans flentem flens acrius ipsa tenebat

Imbre per indignas usque cadente genas. ${ }^{64}$

Logo, porém, que a dor, em si própria, dissipou a bruma do meu espírito e que, finalmente, recuperei os meus sentidos, prestes a partir, dirigi uma última vez a palavra aos meus aflitos amigos, que, se há pouco numerosos, não eram mais do que um ou dois. A minha amada esposa, ela própria chorando amargamente, tinha-me, choroso, entre os seus braços, e uma torrente de lágrimas corria sobre as suas faces inocentes.

Antes de partir, houve tempo para o poeta dirigir uma prece aos deuses. Depois, foi a vez de a esposa orar pelo condenado:

Hac prece adoraui superos ego, pluribus uxor
Singultu medios impediente sonos.

${ }^{60}$ Embora haja quem considere que a relegatio de Ovídio não passa de ficção. Sobre esta problemática, veja-se Miguel Mora (2002) e bibliografia aí aduzida.

${ }^{61}$ Oví́dio «encontrava-se no momento mais "augustano" de todo o seu percurso como poeta, já concluídas as Metamorphoses (embora sem lhes dar a demão final), que termina com a apoteose de César e a celebração de Augusto, e com a elaboração dos Fasti a meio, obra em que se tornava o propagandista da política augustana.» (Miguel Mora (2002) 99). Cícero também se encontrava no auge de uma brilhante carreira política quando foi condenado ao exílio; em 63 a. C. havia alcançado o consulado e denunciado a conspiração de Catilina, proferindo contra este as célebres Catilinárias.

${ }^{62}$ Cícero nasceu no ano 106 a. C. Assim, quando partiu para o exílio em 58, contava já quarenta e oito anos.

${ }^{63}$ Cf. $T r .4 .10 .69-74$.

${ }^{64}$ Tr. 1.3.13-18. Cf. Tr.1.3.61-65; 4.6.45-46. 
Illa etiam ante Lares passis adstrata capillis

Contigit extinctos ore tremente focos

Multaque in aduersos effudit uerba Penates

Pro deplorato non ualitura uiro. ${ }^{65}$

Com tal prece apelei aos deuses, a minha esposa com muitas mais, pois as suas palavras eram entrecortadas com soluços. Prosternada diante dos Lares, com os cabelos em desalinho, ela ainda beijou com a boca tremente os fogos extintos e dirigiu aos Penates adversos inúmeras palavras que iriam ser vãs em favor do desafortunado marido.

Nos momentos derradeiros, tomada pelo desespero, a esposa ainda propôs partir com o marido. A custo, porém, acabou por perceber que the seria mais útil se permanecesse em Roma:

Tum uero coniux umeris abeuntis inhaerens

Miscuit haec lacrimis tristia uerba meis:

"Non potes auelli; simul hinc, simul ibimus, inquit,

Te sequar et coniux exulis exul erro.

Et mibi facta uia est et me capit ultima tellus:

Accedam profugae sarcina parua rati.

Te iubet e patria discedere Caesaris ira,

Me pietas: pietas haec mibi Caesar erit.»

Talia temptabat, sicut temptauerat ante,

Vixque dedit uictas utilitate manus. ${ }^{66}$

Então, na verdade, agarrando-se aos meus ombros enquanto eu partia, misturou a minha esposa estas tristes palavras com as minhas lágrimas: «Não, tu não me podes ser arrebatado! Partiremos juntos, sim, juntos - disse. Seguir-te-ei e serei a esposa exilada de um exilado. $\mathrm{O}$ caminho foi destinado também para mim, também para mim existe um lugar nos confins da terra: ao teu navio de exilado não acrescentarei mais que um pequeno fardo. A cólera de César ordena-te que deixes a pátria, a mim ordena-mo o dever: esse dever será para mim um César.» Tais eram os seus esforços, despendidos já anteriormente, e com relutância se rendeu à consideração dos meus interesses.

Chegou mesmo a desejar a morte, para se libertar da dor que sentia. Por respeito, porém, para com o marido, decide permanecer firme. Para ele, era importante que ela vivesse. A sua sobrevivência iria depender do auxílio que ela lhe pudesse prestar:

Et uoluisse mori, moriendo ponere sensus,

Respectuque tamen non periisse mei.

Viuat et absentem, quoniam sic fata tulerunt,

Viuat et auxilio subleuet usque suo! ${ }^{17}$

\footnotetext{
${ }^{6} \operatorname{Tr}$. 1.3.41-46.

${ }^{66} \operatorname{Tr} .1 .3 .79-88$.

${ }^{67}$ Tr. 1.3.99-102.
} 
Ela quis morrer e, morrendo, deixar de parte os sentimentos, e, no entanto, por respeito a mim, ela não morreu. Quem dera que viva e, na minha ausência, pois assim o quiseram os destinos, que viva e me preste auxílio sem cessar!

Para o poeta afastado da pátria, a esposa era o seu porto de abrigo, o seu amparo nos momentos mais difíceis. Era a ela, graças às acções desencadeadas em Roma, que devia o facto de continuar a ser alguém e de não ter sido espoliado por quem queria aproveitar-se de tão crítica situação:

\section{Te mea subposita ueluti trabe fulta ruina est; Si quid adhuc ego sum, muneris omne tui est. Tu facis ut spolium non sim nec nuder ab illis Naufragii tabulas qui petiere mei. ${ }^{68}$}

Tu és a trave que sustenta a minha ruína; se eu ainda sou alguma coisa, tudo se deve ao teu favor. $\hat{E}$ a ti que devo não ter sido espoliado nem roubado por aqueles que cobiçaram os destroços do meu naufrágio.

Somente a coragem (uirtus) da companheira e de alguns dos seus amigos impedira que tal tivesse acontecido. Segundo o poeta, a dedicação (probitas) da esposa era superior à demonstrada por Andrómaca e Laodamia, que acompanharam os maridos na morte. Devido à natureza do seu próprio carácter ou fruto da educação esmerada que recebera ${ }^{69}$, ela granjeara maior fama que a própria Penélope, tendo-se tornado modelo de esposa virtuosa (exemplum coniugis bonae):
Hunc tua per fortes uirtus submouit amicos,
Nulla quibus reddi gratia digna potest.
(...)
Nec probitate tua prior est aut Hectoris uxor
Aut comes extincto Laodamia uiro.
Tu si Maeonium uatem sortita fuisses,
Penelopes esset fama secunda tuae,
Siue tibi hoc debes, nullo pia facta magistro,
Cumque noua mores sunt tibi luce dati,
Femina seu princeps omnes tibi culta per annos
$\mathrm{Te}$ docet exemplum coniugis esse bonae,

${ }^{68} \operatorname{Tr} .1 .6 .5-8$.

${ }^{69}$ A princesa que, segundo Ovídio, terá ensinado a sua esposa a ser uma mulher virtuosa era Márcia, que havia casado com Paulo Fábio Máximo, tio daquela. A mãe de Márcia, Átia minor, era a irmã mais nova da mãe de Augusto, Átia maior (cf. André (1968) 22, nota 4). A terceira mulher do poeta é geralmente considerada como pertencendo à gens Fabia (cf. Pon. 1.2.136). A sua ligação com Márcia testemunha pelo menos que a sua origem era nobre (cf. AndRÉ (1977) 12, nota 1). Sabe-se que tinha por tio materno Fábio, o destinatário da carta Pon. 2.11, que se preocupou com o 'exílio' de Ovídio, aconselhou a sobrinha e foi encarregado de diversas comissões (cf. ANDRÉ (1977) XXIV). 
Adsimilemque sui longa adsuetudine fecit,
Grandia si paruis adsimulare licet.

A tua coragem impediu-o, graças a amigos destemidos a quem eu jamais conseguirei agradecer dignamente. (...) Em dedicação, nem a esposa de Heitor, nem Laodamia, companheira do marido na morte, te ultrapassaram. Se tivesses encontrado um poeta meónio, a fama de Penélope seria inferior à tua, seja porque deves essas virtudes a ti mesma, o teu sentido do dever não teve nenhum mestre e o teu nobre carácter te foi dado com a aurora, seja porque uma princesa que tu durante anos veneraste te ensina a ser modelo de esposa virtuosa e o longo convívio te tornou semelhante a ela, se é lícito comparar as pequenas coisas com as grandes.

Mesmo in absentia, a esposa dominava os seus pensamentos noite e dia e mantinha um lugar especial no seu coração:

Lassus in extremis iaceo populisque locisque,

Et subit adfecto nunc mibi quicquid abest.

Omnia cum subeant, uincis tamen omnia, coniux,

Et plus in nostro pectore parte tenes.

Te loquor absentem, te uox mea nominat unam;

Nulla uenit sine te nox mibi, nulla dies.

Quin etiam sic me dicunt aliena locutum

$V t$ foret amenti nomen in ore tuum. ${ }^{71}$

Permaneço cansado entre povos e lugares derradeiros, e agora, doente, assaltam-me as lembranças de tudo o que me faz falta. Tudo me vem ao pensamento, mas tu, esposa minha, estás acima de todas as lembranças e deténs a maior parte do meu coração. Apesar de estares ausente, é contigo que falo, é somente a ti que a minha voz chama; não há para mim uma só noite, um só dia que passe sem ti. Dizem até que pronuncio palavras sem sentido, a ponto de o teu nome estar nos meus lábios delirantes.

E a simples perspectiva de vir a reencontrar a mulher dava-lhe alento para continuar a viver:

Si iam deficiam subpressaque lingua palato
Vix instillato restituenda mero,
Nuntiet huc aliquis dominam uenisse, resurgam,
Spesque tui nobis causa uigoris erit. ${ }^{72}$

${ }^{70}$ Tr. 1.6.15-28. Cf. Pon. 3.1.93-94, 105-110. Independentemente dos elogios do marido, a sua uirtus iria ficar para sempre gravada nos versos do poeta: Prima locum sanctas heroidas inter haberes, / Prima bonis animi conspicerere tui./ Quantumcumque tamen praeconia nostra ualebunt, / Carminibus uiues tempus in omne meis. (Tr. 1.6.33-36; cf. Tr. 5.14.1-14).

${ }^{71} \operatorname{Tr}$. 3.3.13-20.

${ }^{72}$ Tr. 3.3.21-24. 
Se eu estivesse a desfalecer e a língua, colada ao palato, somente a custo pudesse ser reanimada por algumas gotas de vinho, se alguém me viesse dizer que a minha senhora tinha vindo para cá, eu reerguer-me-ia, e a esperança de te ver seria a razão da minha força.

A convicção na fidelidade da companheira levava-o a acreditar que eram também de tristeza os dias por ela vividos:

Ergo ego sum dubius uitae, tu forsitan istic

Iucundum nostri nescia tempus agis.

Non agis, adfirmo; liquet hoc, carissima, nobis

Tempus agi sine me non nisi triste tibi. ${ }^{73}$

Não estou, pois, certo de viver, mas tu, talvez, aí, na ignorância da minha sorte, vives dias de felicidade. Não, não vives, tenho a certeza; sei bem, minha querida, que para ti, sem mim, não existem dias que não sejam de tristeza.

Às vezes, porém, as dúvidas assaltavam-no. A distância criava no frágil espírito do poeta sentimentos de insegurança em relação ao amor da mulher:

Quid tamen ipse precer dubito, nec dicere possum

Affectum quem te mentis habere uelim.

Tristis es? Indignor quod sim tibi causa doloris.

Non es? Vt amisso coniuge digna fores. ${ }^{174}$

Não sei, porém, que prece hei-de eu mesmo dirigir, nem sou capaz de dizer que sentimentos gostaria que tu experimentasses. Estás triste? Sinto-me indignado por ser a causa da tua dor. Não estás? Tu devias ser digna do esposo que perdeste!

Esta insegurança levava-o a temer que ela tivesse deixado de o amar como outrora e sentisse vergonha de estar casada com um 'exilado':

Me miserum, si tu, cum diceris exulis uxor,

Auertis uultus et subit ora rubor!

Me miserum, si turpe putas mibi nupta uideri!

Me miserum, si te iam pudet esse meam!

Tempus ubi est illud quo te iactare solebas

Coniuge nec nomen dissimulari uiri?

Tempus ubi est quo te - nisi non uis illa referri-

Et dici, memini, iuuit et esse meam? ?75

Ai de mim, se tu, quando te chamam mulher de exilado, voltas a cara e um rubor invade as tuas faces! Ai de mim, se julgas torpe ser vista como minha

\footnotetext{
${ }^{73} \operatorname{Tr}$. 3.3.25-28.

${ }^{74}$ Tr. 4.3.31-34.

${ }^{75} \operatorname{Tr}$. 4.3.49-56. Cf. Tr. 5.11.1-6.
} 
mulher! Ai de mim, se te envergonha seres minha! Que é daquele tempo em que costumavas orgulhar-te do teu marido e não dissimular o nome dele? Que é do tempo - a não ser que não queiras que isso seja referido - em que te aprazia seres chamada, eu recordo-me, e seres minha?

Exortava-a, por isso, a defender com empenho o marido, cumprindo, desse modo, o seu papel de esposa virtuosa:

Nec tibi, quod saeuis ego sum Iouis ignibus ictus,

Purpureus molli fiat in ore pudor.

Sed magis in curam nostri consurge tuendi

Exemplumque mibi coniugis esto bonae

Materiamque tuis tristem uirtutibus imple. ${ }^{176}$

Não permitas, porque fui atingido pelo sevo raio de Júpiter, que a vergonha core o teu delicado rosto. Mas ergue-te, antes, para me defender, sê para mim o exemplo de uma boa esposa e cumpre o teu difícil papel com as tuas virtudes!

Tomos, o local para onde o edicto imperial o havia atirado, era um lugar remoto, inóspito e ocupado por bárbaros ${ }^{77}$. A esposa de Ovídio deveria, por isso, segundo o poeta, interceder junto de Augusto, para que lhe fosse ao menos permitido cumprir a relegatio num outro lugar:

Vtque uiae casus, ut amara pericula ponti,

Vt taceam strictas in mea fata manus,

Barbara me tellus orbisque nouissima magni

Sustinet et saeuo cinctus ab hoste locus.

Hinc ego traicerer - neque enim mea culpa cruenta est -,

Esset, quae debet, si tibi cura mei.

Ille deus, bene quo Romana potentia nixa est,

Saepe suo uictor lenis in hoste fuit.

Quid dubitas et tuta times? Accede rogaque!

Caesare nil ingens mitius orbis habet. ${ }^{78}$

Ainda que eu cale as desventuras da viagem, os terríveis perigos do mar, ou as mãos armadas contra a minha sorte, retém-me uma terra bárbara, a mais remota do imenso universo, um lugar cercado de sevos inimigos. Eu poderia ser transferido daqui - na verdade, a minha falta não se encontra manchada de sangue - , se o teu amor por mim fosse como devia ser. Esse deus, sobre o qual se funda firmemente o poder de Roma, foi muitas vezes um vencedor misericordioso para com o seu inimigo. Porque hesitas e temes o que não oferece perigo? Vai e suplica-lhe! Não existe ninguém mais amável do que César no imenso universo.

\footnotetext{
${ }^{76}$ Tr. 4.3.69-73. Cf. Tr. 5.11.7-8; 5.14.41-46; Pon. 3.1.61-78.

${ }^{77}$ Cf. Tr. 3.10; Pon. 3.1.1-28.

${ }^{78}$ Tr. 5.2.29-38. Cf. Pon. 3.1.29-30.
} 
Se a esposa the negasse auxílio, sentir-se-ia perdido e desamparado. Dependia inteiramente do seu apoio:

Me miserum! Quid agam, si proxima quaeque relinquunt?

Subtrabis effracto tu quoque colla iugo?

Quo ferar? Vnde petam lassis solacia rebus?

Ancora iam nostram non tenet ulla ratem. ${ }^{79}$

Que desafortunado que eu sou! Que hei-de eu fazer, se todos os que me são próximos me abandonam? Subtrais tu também o teu pescoço ao jugo quebrado? Para onde hei-de eu ir? Aonde hei-de eu ir procurar consolo para as minhas desgraças? Nenhuma âncora segura já o meu navio.

A intervenção da companheira deveria corresponder aos elogios do marido. Ela não deveria defraudar as expectativas dele e, em troca, graças aos seus versos, ficaria célebre para toda a eternidade como modelo de fidelidade conjugal:

Adde quod, ut rerum sola es tutela mearum,

Ad te non parui uenit honoris onus,

Quod nunquam uox est de te mea muta tuique

Indiciis debes esse superba uiri.

Quae ne quis possit temeraria dicere, persta

Et pariter serua meque piamque fidem.

Nam tua, dum stetimus, turpi sine crimine mansit

Et tantum probitas inreprehensa fuit.

Area de nostra nunc est tibi facta ruina:

Conspicuum uirtus bic tua ponat opus!

Esse bonam facile est, ubi quod uetet esse remotum est

Et nibil officio nupta quod obstet habet.

Cum deus intonuit, non se subducere nimbo,

Id demum est pietas, id socialis amor. ${ }^{80}$

Não é tudo: ao assumires sozinha a defesa dos meus interesses, foste incumbida de uma tarefa de grande honra, pois a minha voz jamais se cala sobre ti e tu deves ficar orgulhosa do testemunho do teu marido. Para que ninguém possa dizer que é mentira, mantém-te firme e, de igual maneira, preserva-me a mim e ao teu amor fiel. Na verdade, enquanto me mantive de pé, a tua lealdade permaneceu livre de injúrias torpes e foi simplesmente irrepreensível. Agora, com a minha ruína, criou-se para ti um espaço; que a tua virtude construa aqui uma obra notável! É fácil ser virtuosa quando todo o obstáculo é afastado e nada se opõe ao dever de uma esposa. Mas quando a divindade troveja, não há que fugir da tempestade, é isso precisamente a lealdade, é isso o amor conjugal.

A esposa deveria empenhar todas as suas forças em prol da causa do marido, mais do que qualquer outra pessoa, mais do que qualquer outro amigo:

\footnotetext{
${ }^{79} \operatorname{Tr} .5 .2 .39-42$.

${ }^{80} \operatorname{Tr}$. 5.14.15-28. Cf. Tr. 4.3.79-84; 5.5.49-52; Pon. 3.1.43-48, 57-60.
} 
Pectore te toto cunctisque incumbere neruis

Et niti pro me nocte dieque decet.

Vtque iuuent alii, tu debes uincere amicos,

Vxor, et ad partis prima uenire tuas. ${ }^{81}$

É conveniente que te apliques com todo o coração e com todas as tuas forças e que te empenhes, noite e dia, em prol da minha causa. Para que outros me ajudem, tu, minha esposa, deves fazer mais do que os meus amigos e ser a primeira a cumprir o teu dever.

Bastaria que acrescentasse aos esforços até então empreendidos em favor dele diligências no sentido de conseguir que ele pudesse cumprir a sua pena em paragens menos hostis:
Sed tamen hoc factis adiunge prioribus unum,
Pro nostris ut sis ambitiosa malis,
Vt minus infesta iaceam regione labora,
Clauda nec officii pars erit ulla tui. ${ }^{82}$

Mas acrescenta somente isto àquilo que já fizeste: sê empenhada na resolução dos meus infortúnios, luta para que me seja permitido ficar numa região menos inóspita, e nenhuma parte do teu dever ficará por cumprir.

Para isso, ela teria de interceder junto de Lívia, para assim conseguir chegar a Augusto:

Caesaris est coniunx ore precanda tuo

Quae praestat uirtute sua, ne prisca uetustas

Laude pudicitiae saecula nostra premat,

Quae Veneris formam, mores Iunonis habendo

Sola esta caelesti digna reperta toro. ${ }^{83}$

É necessário que a tua boca implore à esposa de César, a qual, com a sua virtude, assegura que os tempos antigos não ultrapassem no louvor da castidade o nosso século e que, detentora da beleza de Vénus e do carácter de Juno, foi a única considerada digna do leito de um deus.

Empenhado no êxito desta missão, o poeta deu à esposa algumas instruções orientadoras da sua actuação. Primeiramente, para que não fossem em vão os seus esforços, ela teria de começar por escolher o momento oportuno para fazer a abordagem:

Eligito tempus captatum saepe rogandi,

Exeat aduersa ne tua nauis aqua.

\footnotetext{
${ }^{81}$ Pon. 3.1.39-42.

${ }^{82}$ Pon. 3.1.83-86.

${ }^{83}$ Pon. 3.1.114-118.
} 
Non semper sacras reddunt oracula sortis Ipsaque non omni tempore fana patent. ${ }^{84}$

Escolhe bem o momento tantas vezes ensaiado de fazer o pedido, para que o teu navio não saia para correntes adversas. Os oráculos nem sempre entregam as suas sacras profecias e os próprios templos não estão abertos a todo o tempo.

Depois, logo que lhe fosse permitido chegar à fala com a mulher do Imperador, numa atitude de total humildade, deveria prostrar-se a seus pés e, sem nunca defender os actos por ele cometidos, suplicar-lhe a transferência do marido para outro local:

Cum tibi contigerit uultum Iunonis adire,

Fac sis personae quam tueare memor.

Nec factum defende meum: mala causa silenda est.

Nil nisi sollicitae sint tua uerba preces.

Tum lacrimis demenda mora est submissaque terra

Ad non mortalis brachia tende pedes.

Tum pete nil aliud saeuo nisi ab hoste recedam:

Hostem Fortunam sit satis esse mibi. ${ }^{85}$

Quando te couber a sorte de te aproximares do rosto de Juno, lembra-te do papel que tens a desempenhar. Não defendas os meus actos: deve-se silenciar uma má causa. Que as tuas palavras mais não sejam que preces ansiosas. Deverás, então, soltar as lágrimas e, prostrada sobre o chão, estender os braços para os pés dessa imortal. Depois, não peças nada excepto que me seja permitido afastar-me de um inimigo cruel; deixa que a Fortuna seja para mim suficientemente inimiga.

O poeta confiava que a esposa seria bem-sucedida; acreditava na magnanimidade de Lívia, mas, sobretudo, no poder de persuasão da esposa:

Plura quidem subeunt, sed sunt turbata timore;

Haec quoque uix poteris uoce tremente loqui.

Suspicor hoc damno fore non tibi: sentiet illa

Te maiestatem pertimuisse suam.

Nec tua si fletu scindentur uerba, nocebit:

Interdum lacrimae pondera uocis habent. ${ }^{86}$

$\mathrm{Na}$ verdade, vêm-me à mente mais ideias, mas o medo perturba-as; com a voz tremente, tu também dificilmente conseguirás exprimi-las. Penso que não irás sofrer qualquer dano: ela compreenderá que é a sua majestade que te enche de medo. E se as tuas palavras são entrecortadas pelo choro, tal não será prejudicial: por vezes as lágrimas têm o mesmo peso que as palavras.

\footnotetext{
${ }^{84}$ Pon. 3.1.129-132.

${ }^{85}$ Pon. 3.1.145-152.

${ }^{86}$ Pon. 3.1.153-158.
} 
Ovídio confiava, por conseguinte, que a esposa se empenharia na defesa da sua causa.

O casamento ideal e a amizade verdadeira têm muito em comum (o amor ou afecto mútuo, a preocupação com o outro, o altruísmo, a fidelidade, a confiança, a reciprocidade, a partilha de experiências, a sinceridade, a intimidade e o desejo por parte de cada companheiro do melhor para o outro ${ }^{87}$, pelo que o poeta esperava que ela, no apoio prestado ao companheiro, revelasse um grande sentido de lealdade, agindo como uma amiga em quem ele podia confiar inteiramente. Cícero esperara o mesmo da sua esposa. Um contexto especial como era o do exílio levava a que as fronteiras entre amor e amicitia, coniux e amicus se diluíssem, não sendo, por isso, de estranhar que quer Cícero, quer Ovídio tivessem descrito as respectivas companheiras como as suas melhores amigas $^{88}$. $\mathrm{Na}$ verdade, ambos esperavam que elas desempenhassem um papel semelhante ao normalmente desempenhado por indivíduos do sexo masculino seus amigos.

Conforme tivemos oportunidade de referir anteriormente, os antigos Romanos, defensores da ideia de que as mulheres deveriam permanecer confinadas à esfera doméstica, viam como problemático o envolvimento directo de uma mulher em questões de natureza pública. Esse envolvimento era perspectivado como inapropriado e perigoso, já que essas mulheres, ao transporem as fronteiras de actuação tradicionalmente definidas para o seu sexo, ameaçavam subverter a ordem social ${ }^{89}$. No entanto, em contextos verdadeiramente excepcionais, algumas mulheres independentes e corajosas podiam permitir-se tomar decisões por conta própria e intervir politicamente.

$\mathrm{Da}$ análise dos excertos seleccionados de ambos os autores, torna-se evidente que quer a esposa do Sulmonense, quer a mulher do Arpinate desempenharam um papel activo e determinante no auxílio dispensado aos respectivos maridos durante o seu afastamento da pátria. Ambas lhes prestaram apoio emocional, ambas desenvolveram esforços no sentido do regresso ou da aproximação dos companheiros, ambas se mostraram corajosas em todas as diligências tomadas em benefício deles, ambas assumiram posições que, indo além do que, normalmente, thes caberia, as poderiam prejudicar.

Por sua vez, Cícero e Ovídio perspectivavam-nas como mulheres fortes e politicamente empenhadas. Ambos apreciavam e incentivavam a coragem, o poder de decisão e a perseverança das respectivas companheiras, sendo que a inversão dos papéis normalmente reservados a marido e mulher era vista por eles não apenas como natural, mas, sobretudo, como necessária. Em tão peculiares circunstâncias, a superioridade tradicional do homem em relação à

${ }^{87}$ Grebe (2003) 139.

${ }^{88}$ Cf. Grebe (2003) loc. cit., em relação a Cícero; Helzle (1989) 188, relativamente a Ovídio.

${ }^{89}$ Recordem-se os exemplos de Semprónia, Clódia e Fúlvia, referidos anteriormente. O comportamento da primeira foi fortemente criticado por Salústio (cf. Cat. 25); Cícero e Plutarco censuraram Clódia pela sua conduta (cf. Cic., Cael. 30-38, 47-50; Plu., Cic. 29); o carácter e as atitudes de Fúlvia foram severamente criticados por Cícero (cf. Phil. 5.11, 5.22, 2.113), Plutarco (Ant. 10.3, 30.2), D. Cássio (D.C. 47.8.3-4; 48.4.1-6) e Apiano (BC 5.19, 54, 59). Cf. Grebe (2003) 140 sq. 
mulher convertia-se, afinal, num estado de dependência do marido em relação à esposa. Noutras circunstâncias, competiria ao marido olhar pela esposa e pelos interesses familiares. No entanto, a partir do momento em que ele fosse obrigado a viver no exílio, era a ela que competia olhar pelo marido e pela família e ocupar o lugar por ele deixado ${ }^{90}$. Este, remetido a uma posição mais frágil e menos interventiva, não tinha outra opção senão confiar à esposa a gestão das finanças familiares, o desempenho de actividades públicas em prol da sua causa e o seu apoio emocional.

Nesse contexto, e por consequência, ela passava a ser perspectivada por ele, e pela sociedade em geral, como seu par, e a assimetria de poderes, em que tradicionalmente assentava o casamento, adquiria, então, um novo equilíbrio.

\footnotetext{
${ }^{90}$ Cf. GREBE (2003) 144.
} 